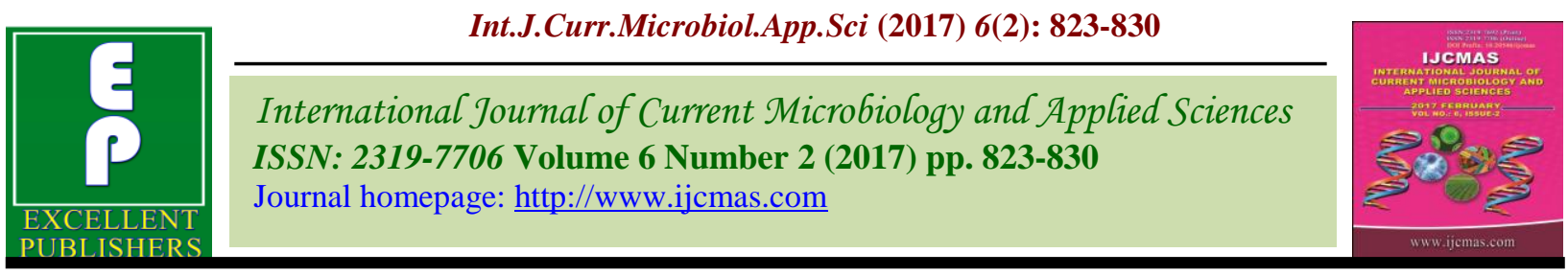

Original Research Article

http://dx.doi.org/10.20546/ijcmas.2017.602.092

\title{
Gross Anatomical Studies on the Pancreas in Prenatal Goat (Capra hircus)
}

\author{
Dharmendra Singh*, Ajay Prakash, M.M. Farooqui, S.P. Singh and Satish K. Pathak \\ Department of Anatomy, College of Veterinary Science \& A.H., Duvasu, \\ Mathura-281001 (U.P), India \\ *Corresponding author
}

\begin{tabular}{|c|c|}
\hline & A B S T R A C T \\
\hline $\begin{array}{l}\text { K e y w o r d s } \\
\text { Pancreas, } \\
\text { Gross anatomical, } \\
\text { Goat, Prenatal. }\end{array}$ & \multirow{3}{*}{$\begin{array}{l}\text { The present study was conducted on the } 24 \text { goat foeti of either sex ranging } \\
\text { from } 42 \text { days to full term gestation. In all goat foeti the pancreas lied in the } \\
\text { abdominal cavity partly on right and partly on left side of median plane. Left } \\
\text { and right lobes were creamy white in color and were fused to form an } \\
\text { irregularly quadrilateral mass. From } 53 \text { days onwards the topographic } \\
\text { location of foetal pancreas was changed in relation to adjacent organs. The } \\
\text { biometric parameters viz: weight, length and width of the pancreas were } \\
\text { significantly increased with the advancement of foetal age. }\end{array}$} \\
\hline Article Info & \\
\hline $\begin{array}{l}\text { Accepted: } \\
\text { 18 January } 2017 \\
\text { Available Online: } \\
\text { 10 February } 2017\end{array}$ & \\
\hline
\end{tabular}

\section{Introduction}

The pancreas plays important role in digestion. It is composed of tubulo-acinar glands that secrete various digestive enzymes such as amylase, lipase and protease. Pancreas develops from dorsal and ventral pancreatic primordia that are outgrowths of endodermal lining at the caudal part of foregut (Mc Geady et al., 2006). In recent years digestion based studies has gained importance because it is directly related to the health and production of the animals. The documentation of normal embryonic and foetal development is necessary to understand the consequences of various developmental stage of gestation (Evans and Sack, 1973). On perusal of literature it has been observed that little attention has been paid towards study of morphogenesis of pancreas especially during the prenatal period of goat. Therefore present research was conducted to record the sequential growth and morphological features during different stage of gestation.

\section{Materials and Methods}

The present study was conducted on the 24 goat foeti of either sex ranging from 42 days to full term gestation. Immediately after collection, the umbilical cord was ligated properly and was cleaned with cotton soaked with water to remove the amniotic fluid. Each embryos/foeti was measured for its crown rump length (CRL) in centimeter with the help of nylon tape and weighed in gram with the aid of electronic weighing balance machine. The approximate age of foeti was 
estimated by using the formula derived by Singh et al., (1979) in goat. The material was divided into early prenatal (0 to 50 days), mid prenatal (51 to 100 days) and late prenatal (101 to till term) periods. For morphometrical studies foeti were dissected carefully from the ventral aspect to expose the pancreas. Shape of pancreas and its topographical location was noticed with respect to the adjacent organs at various stages of prenatal development. Length, width and thickness of right as well as left lobes of pancreas were measured with the help of metric scale, non stretchable thread and vernier calipers and weight of pancreas were measured on electronic weighing balance machine. Morphometry could not be noticed in early prenatal period due to very small size of pancreas. The data generated by biometrical observations were subjected to statistical analysis (Snedecor and Cochran, 1967) with the help of SPSS 17.0 software.

\section{Results and Discussion}

The pancreas of goat foetuses lied in the abdominal cavity partly on right and partly on left side of median plane. It was creamy white in colour and had left and right lobes which were fused to form an irregularly quadrilateral mass. The left lobe was quadrilateral in shape whereas right lobe was irregular.

At 53 days gestation the angles of goat foetus pancreas were relatively acute than later stages and the left and right lobes appeared almost equal in size. The left lobe was in relation with left adrenal gland, ventral part of abomasum and coils of intestine whereas right lobe was related to caudal venacava, caudate lobe of liver and right adrenal gland (Fig. 1). Beyond 53 days the angles of the pancreas became rounded and the right and left lobes were relatively more firmly attached to each other. The left lobe was smaller than the right lobe (Fig. 4, Fig. 5 and Fig. 6). From 59 to 87 days the right lobes had similar relation as mentioned at 53 days stage but the left lobe was related with spleen, left adrenal gland, abomasum and ventral blind sac of rumen. From 91 days onwards the ventral surface of left lobe of the pancreas was related with the junction of dorsal and ventral sac of rumen and part of intestine; its caudal portion was related with left adrenal (Fig. 2). From 101days onwards the right lobe of pancreas in goat foetus was related with caudate and right lobes of liver (Fig. 3).

In mid prenatal period (51 to 100 days gestation) the weight of foetal goat pancreas gradually increased with advancement in age of foetus and the average weight of the foetal goat pancreas was $0.20 \pm 0.03 \mathrm{gm}$. The average weight of the pancreas in this group was 0.11 percent of the average foetal weight. Up to 76 days gestation the right and left lobes of the pancreas did not exhibit much difference in the length and width but beyond it the length of right lobe was relatively more than the left. The average length and width did not exhibit much difference in the left lobe but there was a marked difference in the length and width of right lobe. The average length and width of left lobe were $0.78 \pm 0.07 \mathrm{~cm}$ and $0.71 \pm 0.06$ $\mathrm{cm}$, whereas in right lobe these parameters were $1.20 \pm 0.12 \mathrm{~cm}$ and $0.70 \pm 0.04 \mathrm{~cm}$, respectively. The statistical analysis of data for various parameters viz. weight, length and width of the pancreas were significantly correlated with age of foetus. The weight of the pancreas was highly correlated with age of foetus ( $p>0.01)$ with ' $R$ ' value 0.984 . The length and width of left lobe of the pancreas were highly correlated with age of fetus $(p>0.01)$. The ' $R$ ' value of age of foetus with length and width of left lobe of pancreas were 0.962 and 0.943 . The length and width of right lobe of the pancreas were highly correlated with age of foetus $(p>0.05)$. The ' $R$ ' value of age of foetus with length and width of right lobe of the pancreas were 0.864 and 0.867 (Tables 1 and 2). 
Up to 118 days gestation the weight of pancreas in goat foetus gradually increased with the advancement of age but beyond this stage an abrupt increase in its weight was noticed. The average weight of the pancreas in late prenatal period was $1.00 \pm 0.38 \mathrm{gm}$. which was 0.16 percent of the average foetal weight. In this period the average width of left lobe was nearly $2 / 3^{\text {rd }}$ to its average length whereas in the right lobe it was nearly half to the average length. The average length and width of left lobe were $1.22 \pm 0.04$ and $0.83 \pm 0.046$, whereas in right lobe these parameters were $1.96 \pm 0.16 \mathrm{~cm}$ and $0.92 \pm 0.06$ $\mathrm{cm}$ respectively. The statistical analysis of data for various parameters viz; weight, length and width of the pancreas were significantly correlated with age of foetus. The weight of the pancreas were highly correlated with age of foetus $(p>0.01)$ with ' $R$ ' value 0.989 . The length of left lobe of the pancreas was highly correlated with age of foetus $(p>0.01)$. The ' $R$ ' value of age of foetus with length of left lobe of the pancreas was 0.989. The width of left lobe of the pancreas was highly correlated with age of foetus $(p>0.05)$. The ' $R$ ' value of age of foetus with width of left lobe of the pancreas was 0.824 . The length and width of right lobe of the pancreas were highly correlated with age of foetus $(p>0.05)$. The ' $R$ ' value of age of foetus with length and width of right lobe of the pancreas were 0.944 and 0.844 (Tables 1 and 2).

The statistical analysis of data revealed highly significant difference between the biometrical parameter of the pancreas in goat foetus at mid and late prenatal periods. In late prenatal period, all biometrical parameters of the pancreas increased significantly from mid prenatal period. The average weight of the pancreas increased five times $(0.2 \mathrm{gm}$ to 1.0 gm) than mid prenatal period. The average length of left lobe of the pancreas increased from $0.78 \mathrm{~cm}$ to $1.22 \mathrm{~cm}$, width increased from $0.71 \mathrm{~cm}$ to $0.83 \mathrm{~cm}$. The average length of right lobe of the pancreas increased from $1.2 \mathrm{~cm}$ to $1.96 \mathrm{~cm}$, width increased from 0.70 $\mathrm{cm}$ to $0.92 \mathrm{~cm}$ (Tables 1 and 2).

The foetal goat pancreas was creamy white in colour and was irregularly quadrilateral in shape. Similar shape of pancreas was mentioned in adult ox (Sisson, 1911). In the present study the pancreas of goat foetus consisted of a quadrilateral left lobe and an irregular right lobe which were fused to form an irregularly quadrilateral mass. Mc Geady et al., (2006) reported that a definitive pancreas of domestic animals was the result of dorsal and ventral of pancreas. Singh and Sethi (2012) in buffalo foetus reported two primordia of pancreas at 47 days gestation whereas according to Arey (1954) in human foetus both primordial were 3 to $4 \mathrm{~mm}$ in size. In the present study fused definitive pancreas was first observed at 53 days gestation. Two primordia of pancreas were fused together at $7^{\text {th }}$ week of gestation in man (Arey, 1954) and $15^{\text {th }}$ day of gestation in rabbit (Titlbach and Manakova, 2007). In goat foeti the pancreas lied in the abdominal cavity partly on right and partly on left side of median plane. However, it was situated on the right side of portal vein after birth in ruminants (Getty, 1975) and almost entirely to right of the median plane in ox (Sisson, 1911) (Fig. 3, 5, 6, 7 and 8).

No specific literature was detected on morphological and topographical features of pancreas of domestic animals in prenatal period. However, Sission (1911) and Getty (1975) describe its details in adult ruminants and horse. 
Table.1 Various morphometrical parameters of the pancreas in prenatal goat at different stages of gestation

\begin{tabular}{|c|c|c|c|c|c|c|c|c|}
\hline \multirow[t]{2}{*}{ Groups } & \multirow{2}{*}{$\begin{array}{c}\text { Foetus } \\
\text { Age } \\
\text { (days) }\end{array}$} & \multirow{2}{*}{$\begin{array}{l}\text { CRL } \\
(\mathbf{c m})\end{array}$} & \multirow{2}{*}{$\begin{array}{c}\text { Foetus } \\
\text { Weight } \\
\text { (gm) }\end{array}$} & \multirow{2}{*}{$\begin{array}{c}\text { Pancreas } \\
\text { weight } \\
\text { (gm) }\end{array}$} & \multicolumn{2}{|c|}{ Left lobe $(\mathrm{cm})$} & \multicolumn{2}{|c|}{ Right lobe (cm) } \\
\hline & & & & & Length & Width & Length & Width \\
\hline \multirow{6}{*}{$\begin{array}{c}\text { Early } \\
\text { Prenatal } \\
\text { Period }\end{array}$} & 42 & 3.1 & 1.64 & $(-)$ & $(-)$ & $(-)$ & $(-)$ & $(-)$ \\
\hline & 42 & 3.3 & 1.72 & $(-)$ & $(-)$ & $(-)$ & $(-)$ & $(-)$ \\
\hline & 44 & 4.2 & 2.42 & $(-)$ & $(-)$ & $(-)$ & $(-)$ & $(-)$ \\
\hline & 44 & 4.3 & 2.58 & $(-)$ & $(-)$ & $(-)$ & $(-)$ & $(-)$ \\
\hline & 50 & 4.7 & 6.13 & $(-)$ & $(-)$ & $(-)$ & $(-)$ & $(-)$ \\
\hline & 50 & 4.9 & 6.97 & $(-)$ & $(-)$ & $(-)$ & $(-)$ & $(-)$ \\
\hline \multirow{10}{*}{$\begin{array}{c}\text { Mid } \\
\text { Prenatal } \\
\text { Period }\end{array}$} & 53 & 6.3 & 10.26 & 0.016 & 0.3 & 0.2 & 0.2 & 0.2 \\
\hline & 56 & 7.2 & 15.78 & 0.021 & 0.4 & 0.3 & 0.3 & 0.2 \\
\hline & 59 & 8.1 & 22.06 & 0.027 & 0.3 & 0.3 & 0.4 & 0.3 \\
\hline & 60 & 9.5 & 24.32 & 0.039 & 0.4 & 0.3 & 0.4 & 0.4 \\
\hline & 69 & 11.8 & 55.52 & 0.075 & 0.5 & 0.5 & 0.6 & 0.5 \\
\hline & 76 & 12.5 & 83.73 & 0.146 & 0.7 & 0.6 & 1.1 & 0.7 \\
\hline & 87 & 17.8 & 167.72 & 0.215 & 0.8 & 0.7 & 1.4 & 0.7 \\
\hline & 91 & 18.6 & 205.46 & 0.221 & 0.8 & 0.7 & 1.4 & 0.7 \\
\hline & 94 & 19.7 & 238.73 & 0.262 & 0.9 & 0.9 & 1.3 & 0.8 \\
\hline & 100 & 20.9 & 300.71 & 0.278 & 1.0 & 0.9 & 1.4 & 0.8 \\
\hline \multirow{8}{*}{$\begin{array}{c}\text { Late } \\
\text { prenatal } \\
\text { period }\end{array}$} & 101 & 23.4 & 328.34 & 0.286 & 1.1 & 0.7 & 1.3 & 0.7 \\
\hline & 103 & 24.6 & 346.87 & 0.376 & 1.1 & 0.9 & 1.4 & 0.8 \\
\hline & 107 & 25.4 & 403.45 & 0.437 & 1.1 & 0.7 & 1.8 & 0.8 \\
\hline & 112 & 26.3 & 448.17 & 0.480 & 1.2 & 0.8 & 1.9 & 0.9 \\
\hline & 115 & 27.6 & 545.64 & 0.573 & 1.3 & 0.8 & 2.0 & 0.9 \\
\hline & 118 & 29.7 & 594.06 & 0.726 & 1.3 & 0.8 & 2.2 & 1.1 \\
\hline & 132 & 32.8 & 938.88 & 1.638 & 1.3 & 0.9 & 2.4 & 0.9 \\
\hline & 147 & 37.4 & 1392.17 & 3.487 & 1.4 & 1.1 & 2.7 & 1.3 \\
\hline
\end{tabular}

Note: (-) could not be recorded.

Table.2 Morphometrical parameters (Mean \pm S.E.) and range of pancreas in prenatal goat in various gestation periods

\begin{tabular}{|c|c|c|c|}
\hline \multicolumn{2}{|c|}{ Parameters } & $\begin{array}{l}\text { Mid prenatal period } \\
\text { (Mean } \pm \text { S.E.) }\end{array}$ & $\begin{array}{c}\text { Late prenatal period } \\
\text { (Mean } \pm \text { S.E. })\end{array}$ \\
\hline \multicolumn{2}{|l|}{ Age (days) } & $\begin{array}{l}86.4 \pm 4.7 \\
(69.7-99.8)\end{array}$ & $\begin{array}{l}116.9 \pm 5.4 \\
(101.8-146.7)\end{array}$ \\
\hline \multicolumn{2}{|c|}{ Weight of Foetus (gm) } & $\begin{array}{l}175.3 \pm 38.1 \\
(55.2-300.7)\end{array}$ & $\begin{array}{l}624.69 \pm 129.56 \\
(328.3-1392.2)\end{array}$ \\
\hline \multicolumn{2}{|l|}{ CRL (cm) } & $\begin{array}{l}16.88 \pm 1.55 \\
(11.8-20.9)\end{array}$ & $\begin{array}{l}28.66 \pm 2.75 \\
(20.5-37.4)\end{array}$ \\
\hline \multicolumn{2}{|c|}{ Weight of pancreas (gm) } & $\begin{array}{l}0.20^{\mathrm{a}} \pm 0.03 \\
(0.08-0.28)\end{array}$ & $\begin{array}{l}1.00^{\mathrm{b}} \pm 0.38 \\
(0.29-3.49)\end{array}$ \\
\hline \multirow[t]{2}{*}{ Left lobe } & Length (cm) & $\begin{array}{l}0.78^{\mathrm{c}} \pm 0.07 \\
(0.5-1.0)\end{array}$ & $\begin{array}{l}1.22^{\mathrm{d}} \pm 0.04 \\
(1.1-1.4)\end{array}$ \\
\hline & Width (cm) & $\begin{array}{l}0.71 \pm 0.06 \\
(0.5-0.9)\end{array}$ & $\begin{array}{l}0.83 \pm 0.046 \\
(0.7-1.1)\end{array}$ \\
\hline \multirow[t]{2}{*}{ Right lobe } & Length (cm) & $\begin{array}{l}1.20^{\mathrm{e}} \pm 0.12 \\
(0.6-1.4)\end{array}$ & $\begin{array}{l}1.96^{\mathrm{f}} \pm 0.16 \\
(1.3-2.7)\end{array}$ \\
\hline & Width (cm) & $\begin{array}{l}0.70^{\mathrm{g}} \pm 0.04 \\
(0.5-0.8)\end{array}$ & $\begin{array}{l}0.92^{\mathrm{h}} \pm 0.06 \\
(0.7-1.3)\end{array}$ \\
\hline
\end{tabular}

Figures in parenthesis indicate range. $\mathrm{a}, \mathrm{b}, \mathrm{c}, \mathrm{d}, \mathrm{e}, \mathrm{f}, \mathrm{g}$, and $\mathrm{h}$ superscript showed the significant difference between groups. 
Fig.1 Photograph of 53 days old goat foetus showing pancreas (p), left adrenal gland (la), abomasum (a), rumen (r), spleen (s) and intestine (i).

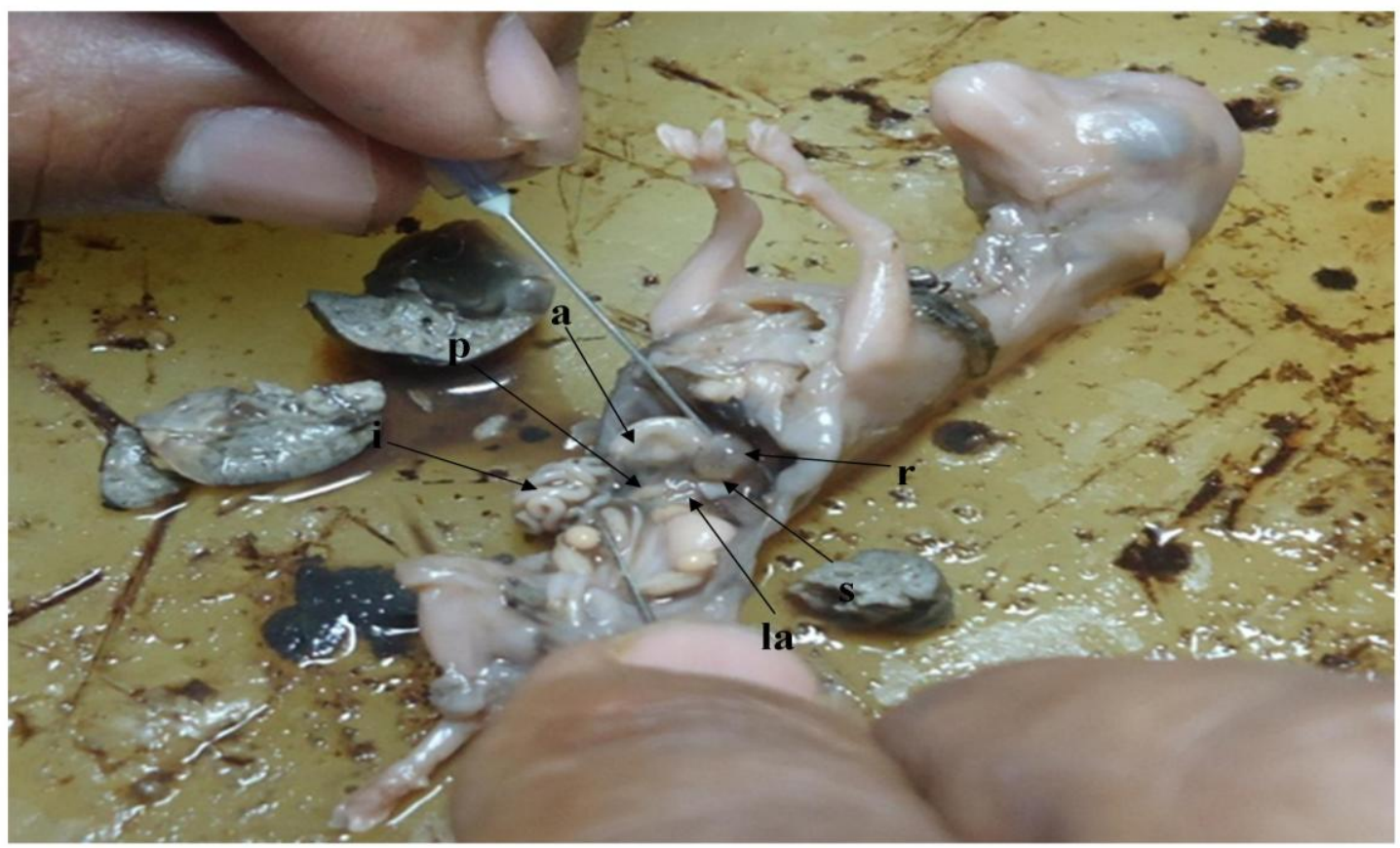

Fig.2 Photograph of 91 days old goat foetus showing left lobe of pancreas (lp), right lobe of pancreas (rp), abomasum (a), rumen (r), left adrenal gland (la) and intestine (i)

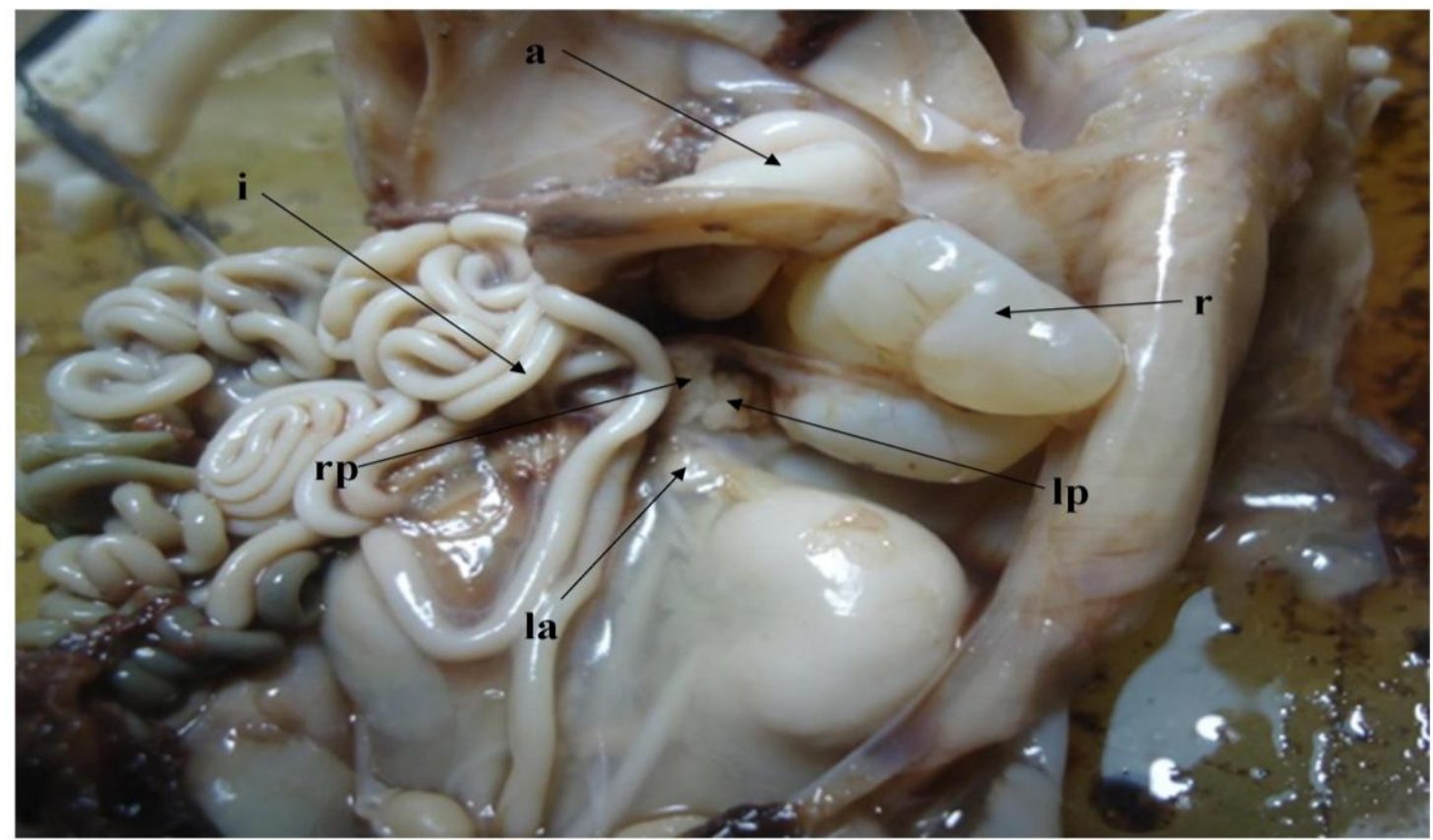


Fig.3 Photograph of full term goat foetus showing right lobe of pancreas (rp), right adrenal gland (ra), right kidney (rk), venacava (v), part of liver (l) and intestine (i)

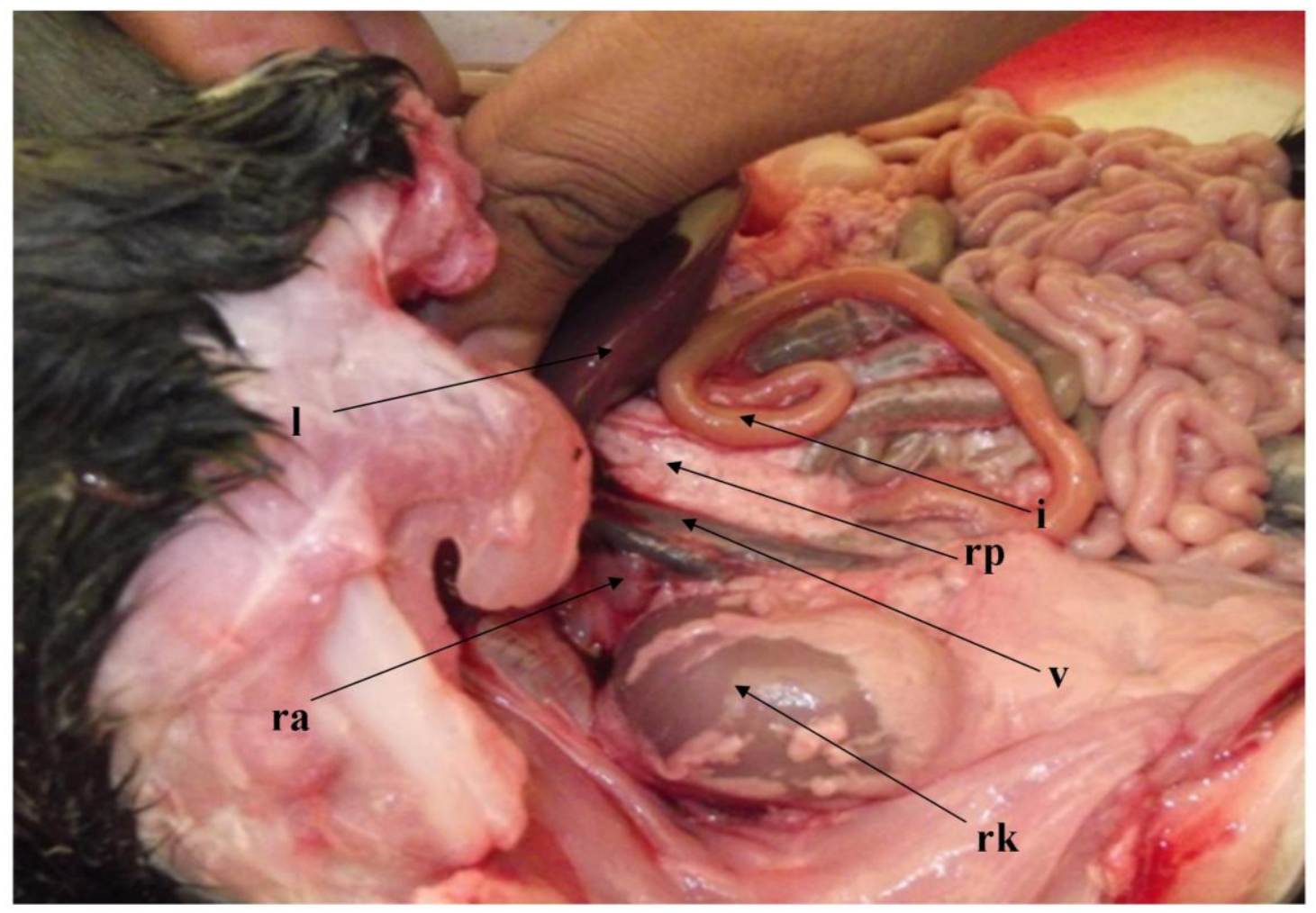

Fig.4 Photograph of 59 days old foetal goat pancreas showing left lobe (L) and right lobe (R).

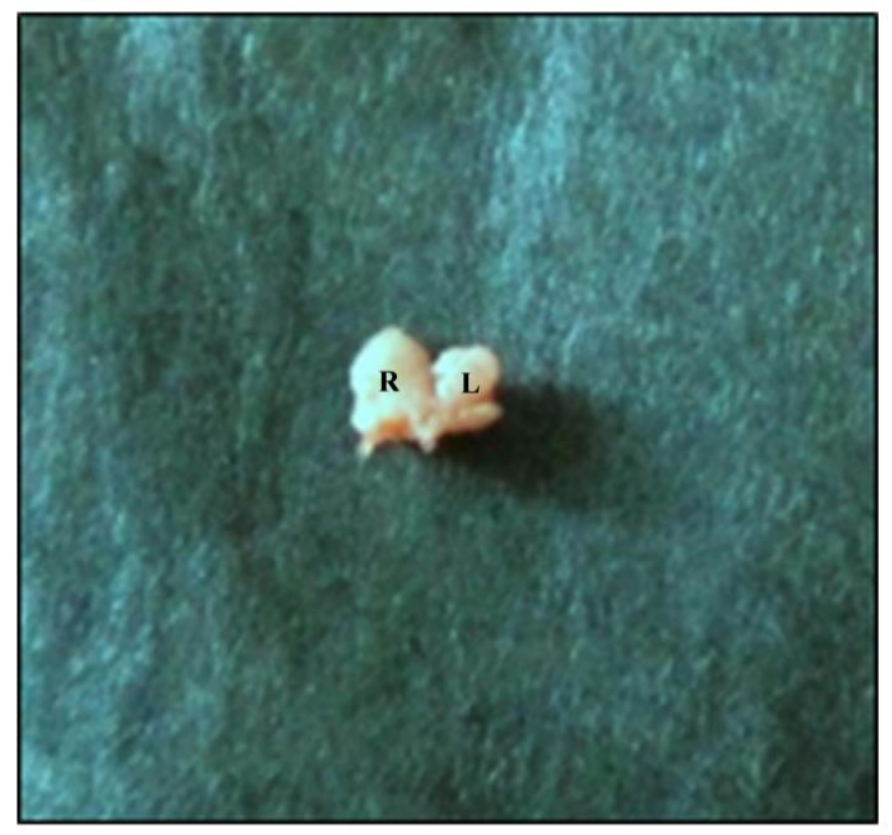


Fig.5 Photograph of 118 days old foetal goat pancreas showing left lobe (L) and right lobe (R).

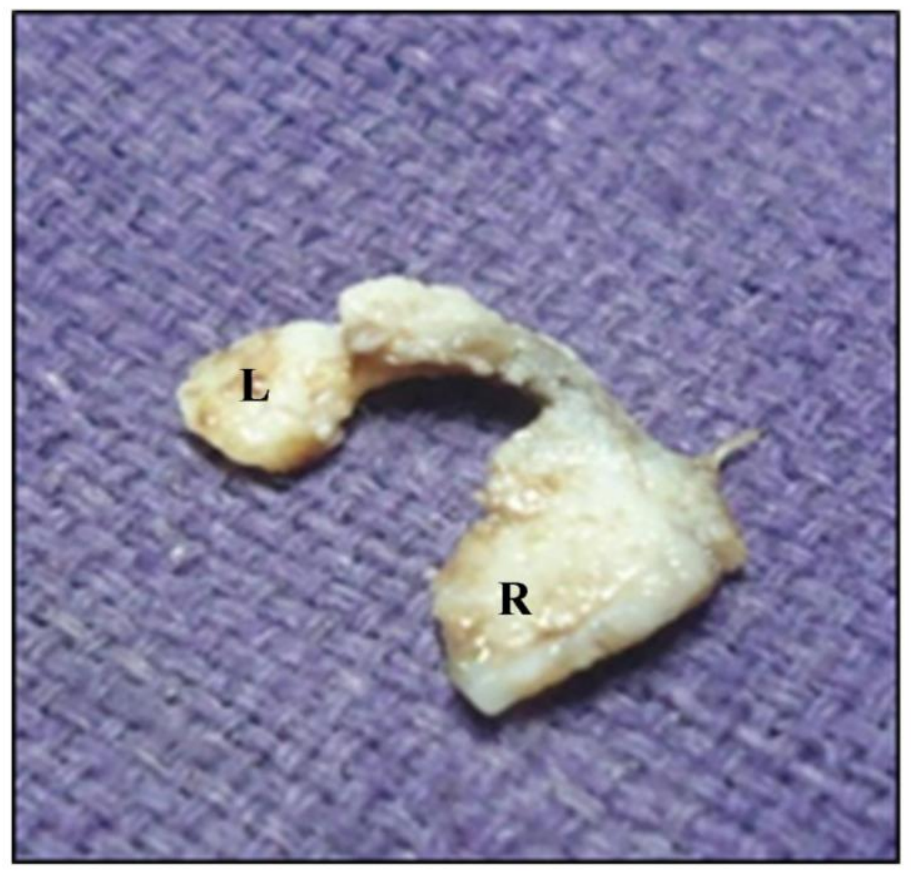

Fig.6 Photograph of full term goat pancreas showing left lobe (L) and right lobe (R).

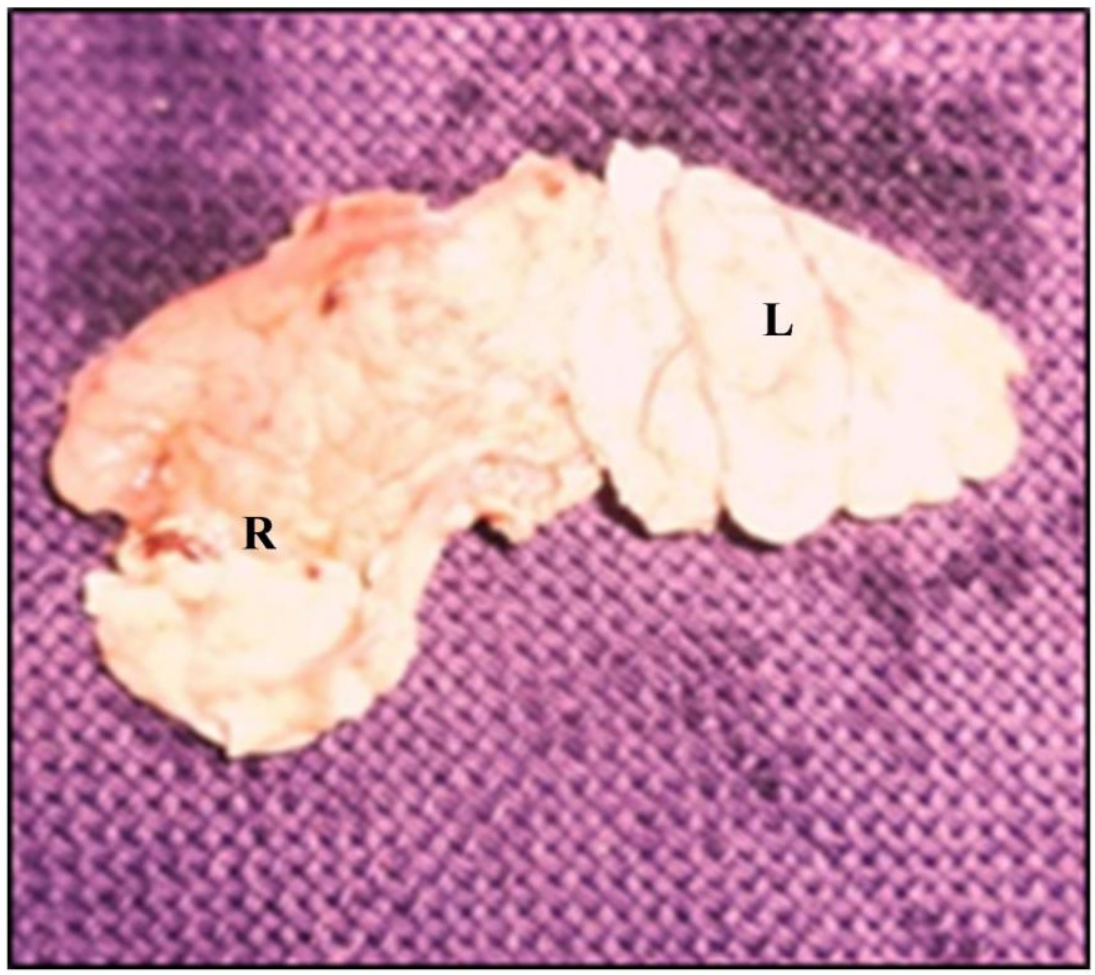

In present study the average weight of the pancreas at full term was 0.25 percent of the average foetal weight. However, according to Sujatha et al., (2012) in human pancreas at 
full term the average weight was 0.09 percent of foetal weight.

The statistical analysis of data revealed highly significant difference between the biometrical parameter of the pancreas in goat foetus at mid and late prenatal periods. In late prenatal period, all biometrical parameters of the pancreas increased significantly from mid prenatal period. The average weight of the pancreas increased five times $(0.2 \mathrm{gm}$ to 1.0 gm) than mid prenatal period. The average length of left lobe of the pancreas increased from $0.78 \mathrm{~cm}$ to $1.22 \mathrm{~cm}$, width increased from $0.71 \mathrm{~cm}$ to $0.83 \mathrm{~cm}$. The average length of right lobe of the pancreas increased from $1.2 \mathrm{~cm}$ to $1.96 \mathrm{~cm}$, width increased from 0.70 $\mathrm{cm}$ to $0.92 \mathrm{~cm}$. The pancreas of goat foetus had gradual increased in all the biometrical parameters throughout gestation. Similar findings were reported by Sujatha et al., (2012) in human foetal pancreas.

\section{References}

Arey, L.B. 1954. Developmental anatomy. $7^{\text {th }}$ edn. W. B. Saunders Company, Philadelphia and London, pp. 260-261.

Evans, H.E. and Sack, W.O. 1973. Prenatal development and laboratory manual. Zbi, Vet. Med. (C) Anatomia Histologia Embryologia, 2: 11-45.
Getty, R. 1975. Sisson and Grossman's. The anatomy of animals. Fifth edn, Vol. 1, pp. 861.

McGeady, T.A., Quinn, P.J., FitzPatrick, E. S. and Ryan, M.T. 2006. Vet. Embryol., Blackwell Publishing Ltd, Oxford OX4 2DQ, UK. pp 213-217.

Sisson, Septimus, S.B.V.S. 1911. A TextBook of Veterinary Anatomy, Philadelphia and London W.B. Saunders Company.

Singh, O. and Sethi R.H. 2012. Histogenesis of pancreas of Indian buffalo (Bubalus bubalis) during prenatal development. Indian Vet. J., 89(11): 56-59.

Singh, Y., Sharma, D.N. and Dhingra, L.D. 1979. Morphogenesis of the testis in goat. Indian J. Animal Sci., 49: 925931.

Snedecor, G.W. and Cochran, W.G. 1967. Statistical methods.6th ed., Oxford and IBH Publishing Co., Calcutta, India.

Sujatha, M., Sugavasi R., Devi, I.V., Sirisha, B., Devi, S.V. and Suneetha, Y., 2012. Morphometry and histogenesis of human foetal pancreas. Int. J. Health Sci. Res., (December issue).

Titlbach, M. and Manakova, E. 2007. Development of the rabbit pancreas with particular regart to the argyrophilic cells. Acta Vet. Brno., 76: 509-517.

\section{How to cite this article:}

Dharmendra Singh, Ajay Prakash, M.M. Farooqui, S.P. Singh and Satish K. Pathak. 2017. Gross Anatomical Studies on the Pancreas in Prenatal Goat (Capra hircus). Int.J.Curr.Microbiol.App.Sci. 6(2): 823-830. doi: http://dx.doi.org/10.20546/ijcmas.2017.602.092 